Viktoriia O. Khrutba ${ }^{1}$, D. S., Department of Ecology and Safety of Vital Functions ORCID ID http://orcid.org/0000-0002-8121-2042,e-mail: Viktoriia.Khrutba@gmail.com

Julia S. Nikitchenko ${ }^{2}, \mathrm{PhD}$, Docent of Department of Environmental Management and Entrepreneurship

ORCID ID http://orcid.org/0000-0003-1487-641X,e-mail: julia_n_s@ukr.net

Lesya I. Kriukovska ${ }^{1}$, PhD, Docent of Department of Ecology and Safety of Vital Functions ORCID ID https://orcid.org/0000-0001-8944-8036,e-mail: krjukovska@gmail.com

Vitalina V. Lukianova ${ }^{1}, \mathrm{PhD}$, Docent of Department of Ecology and Safety of Vital Functions

ORCID ID http://orcid.org/0000-0001-8964-3560,e-mail: vitalina_lk@i.ua

Oksana V. Spasichenko ${ }^{1}$, assistant of Department of Ecology and Safety of Vital Functions ORCID ID https://orcid.org/0000-0002-7809-6765,e-mail: o.spasichenko@ntu.edu.ua

${ }^{1}$ National Transport University, Kyiv, Ukraine

${ }^{2}$ Taras Shevchenko National University of Kyiv, Ukraine

\title{
WAYS OF REDUCTION OF ENVIRONMENTAL RISKS OF SLAG HEAPS OF METALLURGICAL ENTERPRISES, UKRAINE
}

\begin{abstract}
The purpose of this work is a quantitative assessment of the level of reduction of environmental risks of slag heaps of metallurgical enterprises with the use of metallurgical slag as an alternative road construction material.

Methods. Quantitative analysis of the emergence of the risk of environmental hazard is carried out in accordance with the "Methodology for determining the risks and their adopted levels for the declaration of safety of objects of high danger", which determines the procedure for conducting a hazard analysis and risk assessment of high-risk objects, which is carried out through the definition of the probability of undesirable consequences of accidents on based scripts for their emergence and development. For the risk assessment, a logical-probabilistic hazard response scheme in the form of a "failure tree" is constructed and analyzed, which is a form of an ordered graphical representation of the logical-probabilistic connection of random events that results in an undesirable result. The calculation of road surface design with alternative road-building materials is carried out in accordance with the VBN V.2.3-218-186-2004 "Construction of vehicles. Non-rigid type of road clothes" taking into account the requirements of the GBN V.2.3-218-007: 2012 "Environmental requirements for highways Designing".
\end{abstract}

Results. To determine the main causes of environmental hazards in the dumps of metallurgical combines and the nature of their impact on the environment, a tree of problems has been constructed that allows us to determine the main causes of a high level of environmental hazard and the emergence of hazardous situations, namely, the large volumes of metallurgical waste stored on the territory of dumps. For the dumps around the steel mills in Mariupol a "tree of failure" was built and the probability of occurrence of an ecologically dangerous situation or an accident which is connected with places of storage of metallurgical deposits of PJSC "Azovstal Iron and Steel Works" and PJSC "Mariupol Iron and Steel Works named after Ilyich" is calculated. The risk of the risk of storing slags in the dumps of metallurgical combines of the occurrence of the main event is 0.636. The main

(C) В.О. Хрутьба, Ю.С. Нікітченко, Л.І. Крюковська, В.В. Лук’янова, О.В. Спасіченко, 2021 
environmental hazards are the amount of slag and slag dust in the dump area. Design of road clothing with the use of metallurgical slags. The content of metallurgical slag in the proposed designs of the DO reaches $25 \ldots 32 \%$. The use of metallurgical slags, which are low-toxic waste, that is, waste of Class IV hazard, in road construction will reduce the level of existing environmental risk, provided the metallurgical slags of consumer properties.

Scientific novelty. As a result of the performed research, an effective approach to reduce the environmental risks of slag heats of steel mills was identified through the use of large volumes of slag as an alternative road construction material. The design of road clothing for the construction of roads of different categories and the level of reduction of the ecological risk of the dump impact on the environment and health of the population of the region are determined.

Practical significance. The practical application of the proposed approach was made for slag heaps of the metallurgical combines of Mariupol (Ukraine). The level of ecological safety of the region by reducing the amount of metallurgical slags can be increased by $27-30 \%$, which will allow the company to obtain a total ecological and economic effect in the amount of 1.22 million UAH.

Key wards: metallurgical slag; dumps of metallurgical combines; environmental risks; construction of road clothes

\title{
В.О. Хрутьба ${ }^{1}$, Ю.С. Нікітченко ${ }^{2}$, Л.І. Крюковська ${ }^{1}$, В.В. Лук'янова ${ }^{1}$, О.В. Спасіченко ${ }^{1}$
}

${ }^{1}$ Національний транспортний університет, Київ, Україна

${ }^{2}$ Київський національний університет імені Тараса Шевченка, Київ, Україна

\section{ШЛЯХИ ЗНИЖЕННЯ ЕКОЛОГІЧНИХ РИЗИКІВ ШЛАКОВИХ ВІДВАЛІВ МЕТАЛУРГІЙНИХ КОМБІНАТІВ, УКРАЇНА}

\begin{abstract}
Анотація. Метою иієї роботи є кількісна оцінка рівня зниження екологічних ризиків илакових відвалів металургійних підприємств при використанні металургійних шлаків як альтернативного дорожньо-будівельного матеріалу.
\end{abstract}

Методика. Кількісний аналіз виникнення ризику екологічної небезпеки здійснюється за "Методикою визначення ризиків і їх прийнятних рівнів для декларування безпеки об'єктів підвищеної небезпеки", яка визначає порядок проведення аналізу небезпеки та оиінки ризику об'єктів підвищеної небезпеки, що здійснюється через визначення ймовірності небажаних наслідків аварій на основі сиенаріїв їх виникнення та розвитку. Для оцінки ризику побудована та проаналізована логіко-ймовірнісна схема виникнення небезпеки у вигляді "дерева відмов", яке є формою упорядкованого графічного зображення логікоймовірнісного зв'язку випадкових подій, що призводять до небажаного результату. Розрахунок конструкиій дорожнього одягу (КДО) 3 альтернативними дорожньо-будівельними матеріалами здійснюємо згідно 3 ВБН В.2.3-218-186-2004 "Споруди транспорту. Дорожній одяг нежорсткого типу" з урахуванням вимог ГБН В.2.3-218-007:2012 "Екологічні вимоги до автомобільних доріг. Проектування".

Результати. Для визначення основних причин екологічних небезпек у відвалах металургійних комбінатів та характеру їх впливу на довкілля побудовано дерево проблем, що дозволяє визначити основні причини високого рівня екологічної небезпеки та виникнення небезпечних ситуацій, а саме великі обсяги металургійних відходів, щяо зберігаються на території відвалів. Для відвалів навколо металургійних комбінатів м. Маріуполя побудовано "дерево 
відмов" та розраховано ймовірність виникнення екологічно-небезпечної ситуації або аварії, які пов'язані з місиями зберігання шлаків металургійних ПрАТ "Металургійний комбінат Азовсталь" та ПрАТ "Маріупольський металургійний комбінат імені Ілліча". Ризик небезпеки збереження шлаків у відвалах металургійних комбінатів виникнення головної подї становить 0, 636. Основними факторами, щуо створюють екологічну небезпеку, є наявний обсяг илаків та шлакового пилу на території відвалу. Розроблено конструкиії дорожнього одягу $з$ використанням металургійних илаків. Вміст металургійного шлаку в запропонованих конструкціях ДО досягає $25 . .32 \%$. Використання металургійних илаків, які $\epsilon$ малотоксичними відходами, тобто відходами IV класу небезпеки, у дорожньому будівництві дозволить знизити рівень наявного екологічного ризику за умови надання металургійним шлакам споживчих властивостей.

Наукова новизна. В результаті виконаних досліджень було визначено ефективний підхід зниження екологічних ризиків илакових відвалів металургійних комбінатів за рахунок використання великих обсягів шлаків як альтернативного дорожньо-будівельного матеріалу. Визначено конструкцію дорожнього одягу для будівництва доріг різної категорії та рівень зниження екологічного ризику впливу відвалу на довкілля та здоров 'я населення регіону.

Практична значущість. Практичне застосування запропонованого підходу здійснено для шлакових відвалів металургійних комбінатів м. Маріуполя (Україна). Рівень екологічної безпеки регіону за рахунок зменшення обсягу металургійних шлаків може бути підвищений на 27-30\%, щуо дозволить підприємству одержати сумарний еколого-економічний ефект у сумі 1,22 млн грн.

Ключові слова: металургійні илаки; відвали металургійних комбінатів; екологічні ризики; конструкція дорожнього одягу

DOI: $10.32347 / 2411-4049.2021 .2 .39-54$

\section{Постановка проблеми}

Україна, за даними World Steel Association, зберігає провідне місце по виробництву металопродукції і традиційно займає 11-12 місця в світовому рейтингу $[1,2]$.

Виробництво металопрокату в Україні сьогодні забезпечується об’єднанням підприємств "Укрметалургпром", головною метою якого $є$ створення сприятливих умов для ефективної роботи та стабільного розвитку гірничо-металургійного комплексу України. За оперативними даними [3], за 12 місяців 2018 р. українськими металургами вироблено: залізорудного концентрату 60,32 млн т; агломерату 31,68 млн т; коксу 10,83 млн т; чавуну 20,56 млн т; сталі 21,1 млн т; прокату 18,36 млн т; трубної продукції 1,1 млн т.

В той самий час, металургійне виробництво $є$ одним із найбільших забруднювачів навколишнього середовища. Підприємства чорної металургії генерують близько 15\% всіх промислових викидів в атмосферу пилу, 8-10\% викидів діоксиду сірки, 10-15\% - загального обсягу споживання води. Викиди від стаціонарних джерел таких підприємств досягають 38\% від загальної кількості забруднюючих речовин в Україні. До цього слід додати величезну кількість твердих промислових відходів (шлаків, шламів тощо) [4, 5]. Відходи металургії утворюються вже на стадії видобутку руди. Існуючі технології не можуть забезпечити ефективну переробку природних ресурсів, внаслідок чого понад 90\% їх потрапляє у відходи. Площі, які займають кар'єри, розрізи, 
відвали, хвостосховища, шлаконакопичувачі, терикони, сміттєзвалища, складають понад 10\% від загальної території України. За даними В.Д. Рудь, І.В. Савюк, Л.М. Самчук, Ю.С. Повстяна [6, 7], на металургійних підприємствах України накопичено понад 240 млн т шлаків.

Шлакові відвали відходів чорної та кольорової металургії, гірничозбагачувальних комбінатів завдають серйозної шкоди довкіллю і здоров’ю людини. Вони займають величезні площі, забруднюють токсичними сполуками грунти, водний і повітряний басейни, підвищують собівартість готової продукції підприємств із-за значних витрат на їх транспортування, розміщення і зберігання. В той самий час, відходи металургійних виробництв можуть бути використані як сировина i матеріали для будівництва або капітального ремонту доріг, що зможе суттєво зменшити рівень екологічних ризиків їх негативного впливу на довкілля та здоров'я людини. Отже, визначення шляхів зниження екологічних ризиків шлакових відвалів металургійних комбінатів $є$ дуже актуальним.

За сучасних умов інтенсифікація темпів дорожнього будівництва потребує пошуку альтернативних аналогів природним будівельним матеріалам. До них відносять і шлакові матеріали, які є відходами металургійного виробництва. Застосування металургійних шлаків як замінника природних будівельних матеріалів у дорожньому будівництві є одним з основних напрямків зниження матеріаломісткості цього масового багатотоннажного виробництва [8].

Таким чином, актуальним та перспективним є напрям зниження рівня екологічних ризиків шлакових відвалів металургійних комбінатів за рахунок їх використання у дорожньому будівництві, що передбачає суттєве зменшення кількості шлаків у відвалах, отже, зниження їх впливу на довкілля.

\section{Аналіз останніх досліджень і публікацій}

Питанню підвищення рівня екологічної безпеки при поводженні з відходами металургійних підприємств присвячено багато наукових досліджень.

Екологічні наслідки впливу шлакових відвалів на довкілля досліджуються в роботах багатьох науковців. Більшість шлаків містять домішки токсичних елементів, таких як $\mathrm{As}, \mathrm{Pb}, \mathrm{Cd}, \mathrm{Co}, \mathrm{Cr}$ або $\mathrm{Ni}$ та ін. (В.С. Лесовик, М.С. Агеева, А.В. Іванов). Однак, оскільки ці речовини можуть вимиватися зі шлаків, то екологічні ризики не завжди можливо виключити [9].

Ефективні методи управління відходами металургійного виробництва представлено в дослідженнях Т.Г. Данилової [10]. Автором досліджено вплив компонентів шлаку на здоров'я населення, що проживає в зонах шлакових відвалів та працюючих на промислових підприємствах, зайнятих на виробництвах 3 обслуговування відходів металургійного виробництва, систематизовані види захворювань у залежності від впливу компонентів у шлаку. Визначено межі екологічного ризику для ефективного управління ним.

В дослідженнях Ю.Т. Котова, Ф.С. Разкевич, К.В. Гончарова проведено аналіз утворення відходів металургійного виробництва і розробка методів їх повторного використання на ПАТ "АрселорМіттал Кривий Ріг" [11]. В роботах $[12,13]$ проаналізовано екологічні ризики та екологічну небезпеку впливу шлакових відвалів на навколишнє середовище, запропоновано метод переробки, який дає змогу зменшувати нагромадження їх та, відповідно, підвищувати рівень екологічної безпеки об'єкта, регіону. В [14] визначено 
показники екологічної безпеки проектів використання відходів як дорожньобудівельного матеріалу.

Проте, подальшого дослідження потребує питання визначення рівня зменшення екологічного ризику для відвалів металургійних комбінатів при використанні великих їх обсягів як альтернативного дорожньо-будівельного матеріалу.

\section{Мета статті}

Метою цієї роботи є кількісна оцінка рівня зниження екологічних ризиків шлакових відвалів металургійних підприємств при використанні металургійних шлаків як альтернативного дорожньо-будівельного матеріалу. Практичне застосування запропонованого підходу здійснено для шлакових відвалів металургійних комбінатів м. Маріуполя (Україна).

\section{Методика дослідження}

Найбільш розвинутими методами оцінки впливу підприємства на довкілля є: економічний аналіз природоохоронної діяльності; еколого-економічні методи досліджень; оцінка технологічних змін у виробництві; аналіз альтернативної вартості природоохоронних заходів; витрати, що пов'язані 3 вартістю відновлення здоров'я та лікування [15]. Критерії "екологічного ризику" оцінюють екологічну безпеку через ймовірність виникнення аварії і величину збитку. Для кількісного аналізу виникнення ризику екологічної небезпеки можна використати "Методику визначення ризиків і їх прийнятних рівнів для декларування безпеки об'єктів підвищеної небезпеки" [16], яка визначає порядок проведення аналізу небезпеки та оцінки ризику об'єктів підвищеної небезпеки. Методика полягає у визначенні ймовірності небажаних наслідків аварій на основі сценаріїв їх виникнення та розвитку. Критерії "екологічного ризику" оцінюють екологічну безпеку через ймовірність виникнення аварії і величину збитку. Оцінка ризику може виконуватися побудовою та аналізом логіко-ймовірнісної схеми виникнення небезпеки у вигляді "дерева відмов", яке $\epsilon$ формою упорядкованого графічного зображення логіко-ймовірнісного зв'язку випадкових подій, що призводять до небажаного результату. Базисні події поєднуються між собою логічними елементами, які інформують про результат події. "I" - вихідна подія відбувається, якщо всі вхідні події трапляються одночасно. "АБО" - вихідна подія відбувається, якщо трапляється будь-яка 3 вхідних подій. Вираз для визначення ймовірності настання головної події в разі логічного символу "I" має вигляд:

$$
P_{I}=P_{I I} P_{I I I}
$$

Якщо вхідні події поєднуються знаком "АБО", то результуюча подія можлива, коли відбудеться хоча б одна (будь-яка) з вхідних подій. Вираз для визначення ймовірності настання головної події в разі логічного символу "АБО":

$$
P_{I}=1-\left(1-P_{I I}\right)\left(1-P_{I I I}\right)
$$


Розрахунок конструкцій дорожнього одягу (КДО) 3 альтернативними дорожньо-будівельними матеріалами здійснюємо згідно з ВБН В.2.3-218-1862004 "Споруди транспорту. Дорожній одяг нежорсткого типу" [17] з урахуванням вимог ГБН В.2.3-218-007:2012 "Екологічні вимоги до автомобільних доріг. Проектування" [18].

\section{Результати та їх обговорення}

У більшості відвалів металургійних комбінатів шлакові відходи складуються переважно без спеціальної обробки i, найчастіше, займають до 40\% території підприємства. Шкідливий вплив здійснюється на здоров'я як населення прилеглих територій, так і працівників підприємства. Вплив на здоров'я працюючих пов'язаний $з$ утворенням газів та парів летких легкоплавких компонентів, гарячого пилу тощо. Вплив на здоров'я населення пов'язаний 3 впливом гарячого пилу, летких компонентів і газів при зливі шлаку у відвал, постійною газацією відвалу, систематичним подрібненням шлаку, виділенням пилу, вторинною газацією. Все це викликає захворювання дихальних шляхів і очей [14].

Шлаки, вивезені у відвали, не тільки займають великі території культурних земель, але i $€$ причиною забруднення повітряного i водного басейнів. Здійснюється постійний вплив процесів вітрової ерозії, розмивання поверхні відвалу опадами, поптрапляння шкідливих речовин в поверхневий пригрунтовий шар, в грунтові води, водоймища тощо.

При хімічному вивітрюванні шлакових мінералів, у тому числі сульфідів і нітридів, у водному середовищі відбувається різке підвищення $\mathrm{pH}$, 3'являються такі сполуки, як сірководень, нітрити, нітрати, можливо, аміак, деякі метали, вміст яких у водному середовищі лімітується екологічними нормативами. Скрізь, де є металургійні шлаки, у водоймах накопичуються води з надзвичайно високою концентрацією сульфідів, які іноді прориваються в струмки і річки, в результаті рукотворних паводків, що призводить до сильного забруднення та виникнення техногенних аварій. Кисень у воді витрачається на окислення сульфідів, вміст кисню в даних сульфідних водоймах стає рівним нулю, і це призводить до загибелі живих організмів [19].

Основні види впливу відходів металургійних підприємств на НС наведено в табл. 1.

Таблиця 1 - Основні впливи шлакових відвалів на довкілля

\begin{tabular}{|c|c|c|c|c|}
\hline Грунти та ландшафт & $\begin{array}{l}\text { Водоймища та } \\
\text { грунтові води }\end{array}$ & Атмосфера & Фізичні & Соціальні \\
\hline $\begin{array}{l}\text { Порушення ландшафту, } \\
\text { порушення рівноваги } \\
\text { геологічного, фізичного } \\
\text { та механічного стану }\end{array}$ & \begin{tabular}{|l|} 
Зміна \\
гідрологічного \\
режиму прилеглих \\
територій
\end{tabular} & \multirow[t]{2}{*}{$\begin{array}{l}\text { Пило-газове } \\
\text { забруднення } \\
\text { атмосфери }\end{array}$} & \multirow{2}{*}{$\begin{array}{l}\text { Шумовий та } \\
\text { вібраційний } \\
\text { вплив на } \\
\text { флору і } \\
\text { фауну } \\
\text { прилеглих } \\
\text { територій }\end{array}$} & \multirow{2}{*}{$\begin{array}{l}\text { Створення } \\
\text { підвищеної } \\
\text { небезпеки на } \\
\text { здоров'я } \\
\text { населення, } \\
\text { що проживає } \\
\text { в зонах } \\
\text { шлакових } \\
\text { відвалів }\end{array}$} \\
\hline \multicolumn{2}{|c|}{$\begin{array}{l}\text { Хімічне і радіаційне забруднення грунтів та } \\
\text { вод, вимивання та видування шкідливих } \\
\text { компонентів }\end{array}$} & & & \\
\hline
\end{tabular}


Дерево проблем, яке визначає основні причини екологічних небезпек у відвалах металургійних комбінатів та характеризує їх вплив на довкілля (рис. 1), дозволяє встановити, що основною причиною високого рівня екологічної небезпеки та виникнення небезпечних ситуацій є великі обсяги металургійних відходів, які зберігаються на території відвалів.

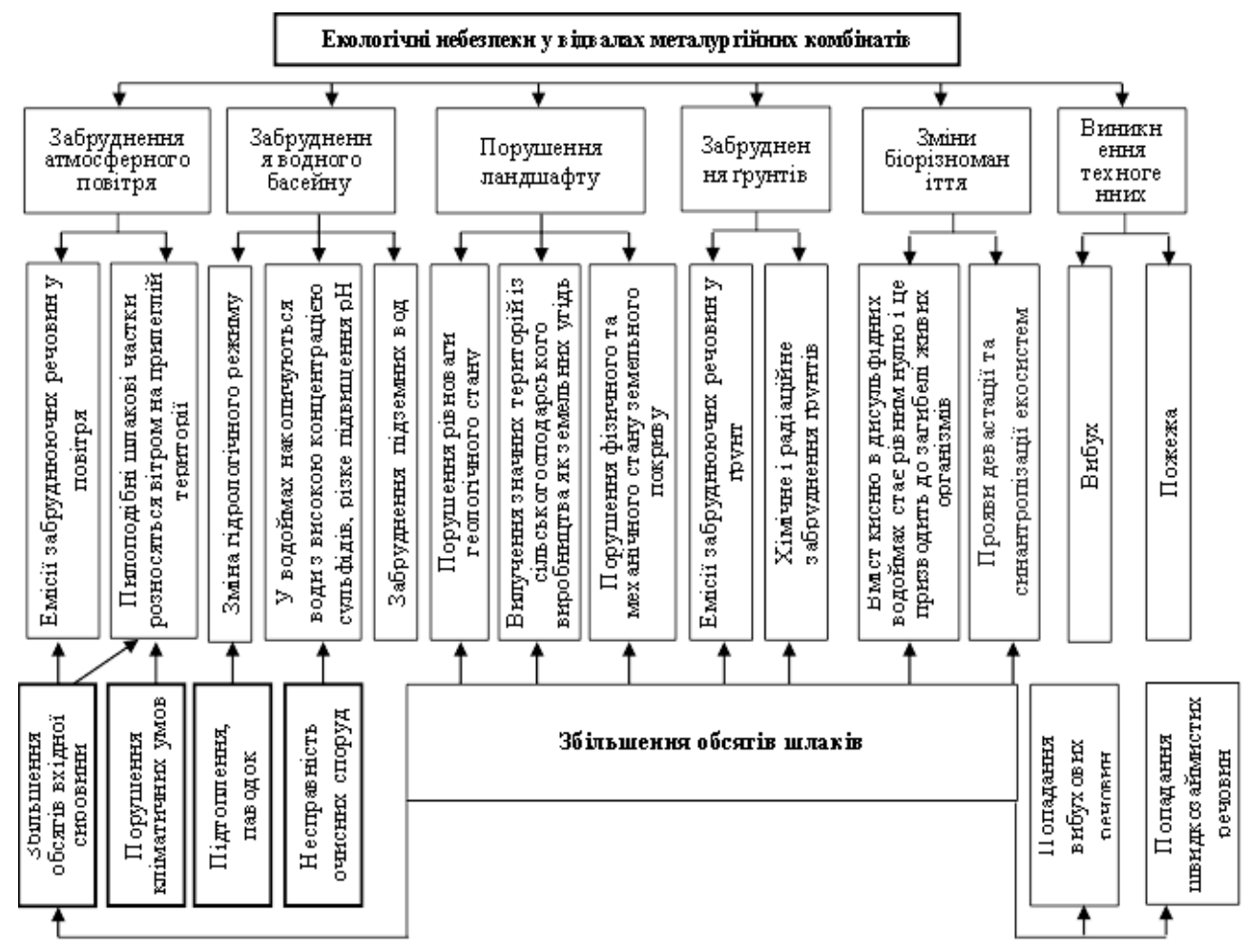

Рис. 1 - Дерево проблем впливу відвалів металургійних шлаків на навколишнє середовище

Для оцінки очікуваного ризику в роботі використовували фрагмент розробленого "дерева подій". Для відвалів навколо металургійних комбінатів м. Маріуполя побудовано "дерево відмов", як графічне зображення логікоймовірнісного зв'язку випадкових подій, що призводять до небажаного результату (рис. 2). Розрахунок локальних екологічних ризиків від збереження шлаків у відвалах здійснювався на основі статистичних даних Департаменту екології та природних ресурсів Донецької обласної державної адміністрації [20]. Об'єктами екологічної небезпеки в м. Маріуполь, які загрожують національній безпеці, економіці, здоров'ю або безпеці життєдіяльності населення, визнано ПрАТ "Металургійний комбінат Азовсталь" та ПрАТ "Маріупольський металургійний комбінат імені Ілліча". Ці підприємства $є$ основними накопичувачами промислових відходів.

Станом на 31.12.2017 загальний обсяг накопичених відходів ПрАТ "Маріупольський металургійний комбінат імені Ілліча" складав 35856,73 тис. т, а ПрАТ "Металургійний комбінат Азовсталь" 45 722,64 тис. т. 39\% всіх відходів ПрАТ "Маріупольський металургійний комбінат імені Ілліча" припадає на шлаки доменні, 3 яких 3864,81 тис. т 
зберігається на підприємстві, а 14 069,48 тис. т - у місцях зберігання відходів. Шлаки доменні ПрАТ "Металургійний комбінат Азовсталь" складають 64\% всіх відходів підприємства, а саме 29 317,82 тис. т, які зберігаються у місцях видалення відходів.

Характеристика місць видалення відходів ПрАТ "Металургійний комбінат Азовсталь" та ПрАТ "Маріупольський металургійний комбінат імені Ілліча" представлена в табл. 2.

Таким чином, загальна кількість фактично накопичених відходів станом на 01.01.2018 від діяльності ПрАТ "Металургійний комбінат Азовсталь" та ПрАТ "Маріупольський металургійний комбінат імені Ілліча" становить 91 142,1 тис. т. Ці відходи займають площу 281,39 га. Отже, на 1 га знаходиться 323,9 тис. т відходів. Рівень утилізації відходів за 2017 рік складає 22,4\% від утворених. Загальна кількість доменних шлаків 43 387,3 тис. т, що складає 47,6\% від загальної кількості відходів. Шлаки доменні займають площу 134 га.

Таблиця 2 - Характеристика місць видалення відходів металургійних комбінатів м. Маріуполя

\begin{tabular}{|c|c|c|c|c|c|c|}
\hline \multirow[t]{2}{*}{$\begin{array}{l}\text { № } \\
\text { 3/ח }\end{array}$} & \multirow{2}{*}{$\begin{array}{l}\text { Назва місця видалення } \\
\text { відходів (за наявності), } \\
\text { місце розташування }\end{array}$} & \multirow{2}{*}{$\begin{array}{l}\text { Режим } \\
\text { функціо- } \\
\text { нування }\end{array}$} & \multicolumn{2}{|c|}{$\begin{array}{l}\begin{array}{l}\text { Координати об'єкта } \\
\text { (формат WGS84) }\end{array} \\
\end{array}$} & \multirow{2}{*}{\begin{tabular}{|l|} 
Фактично \\
накопичено \\
на 1.01 .2018$, \\
тис. т \\
\end{tabular}} & \multirow[t]{2}{*}{$\begin{array}{l}\text { Фактична } \\
\text { площа, га }\end{array}$} \\
\hline & & & \begin{tabular}{|l} 
географічна \\
широта
\end{tabular} & $\begin{array}{l}\text { географічна } \\
\text { довгота }\end{array}$ & & \\
\hline \multicolumn{7}{|c|}{ ПрАТ "Маріупольський металургійний комбінат імені Ілліча" } \\
\hline 1 & $\begin{array}{l}\text { Грековата. на північ } \\
\text { від с. Приморське }\end{array}$ & Діюче & 47.203481 & 37.669196 & 28722,35 & 177,44 \\
\hline 2 & $\begin{array}{l}\text { Старо-Кримський } \\
\text { кар'єр }\end{array}$ & Закрите & 47.174766 & 37.506243 & 2240,60 & 7,2 \\
\hline 3 & $\begin{array}{l}\text { Шламонакопичувач } \\
\text { №1 цеху холодної } \\
\text { прокатки }\end{array}$ & Діюче & 47.180159 & 37.544554 & 1523,175 & 12 \\
\hline 4 & $\begin{array}{l}\text { Шламонакопичувач } \\
\text { №2 цеху холодної } \\
\text { прокатки }\end{array}$ & Закрите & 47.178522 & 37.549647 & 60,00 & 1,8 \\
\hline \multicolumn{7}{|c|}{ ПрАТ "Металургійний комбінат Азовсталь" } \\
\hline 5 & $\begin{array}{l}\text { Склади (відвали) у } \\
\text { південно-східній } \\
\text { частині комбінату }\end{array}$ & Діюче & 47.090497 & 37.613877 & 29802,47 & 49,8 \\
\hline 6 & $\begin{array}{l}\text { Звалище промислов. } \\
\text { відходів на території } \\
\text { комбінату }\end{array}$ & Діюче & 47.094171 & 37.612577 & 5154,73 & 14,4 \\
\hline 7 & $\begin{array}{l}\text { Шламонакопичувач } \\
\text { в акваторії } \\
\text { Азовського моря }\end{array}$ & Діюче & 47.089047 & 37.599855 & 1600,47 & 56 \\
\hline 8 & $\begin{array}{l}\text { Золонакопичувач } \\
\text { в акваторії } \\
\text { Азовського моря } \\
\end{array}$ & Діюче & 47.083478 & 37.589046 & 9536,00 & 53,5 \\
\hline 9 & $\begin{array}{l}\text { Акваторія захисної } \\
\text { дамби }\end{array}$ & $\begin{array}{l}\text { Законсер- } \\
\text { вов. }\end{array}$ & 47,084894 & 37,607615 & 12331,80 & 79,19 \\
\hline 10 & $\begin{array}{l}\text { Накопичувач } \\
\text { хімічних відходів }\end{array}$ & Закрите & 47.188446 & 37.674731 & 170,50 & 7,5 \\
\hline \multicolumn{2}{|r|}{ Загалом } & & & & 91142,1 & 281,39 \\
\hline
\end{tabular}




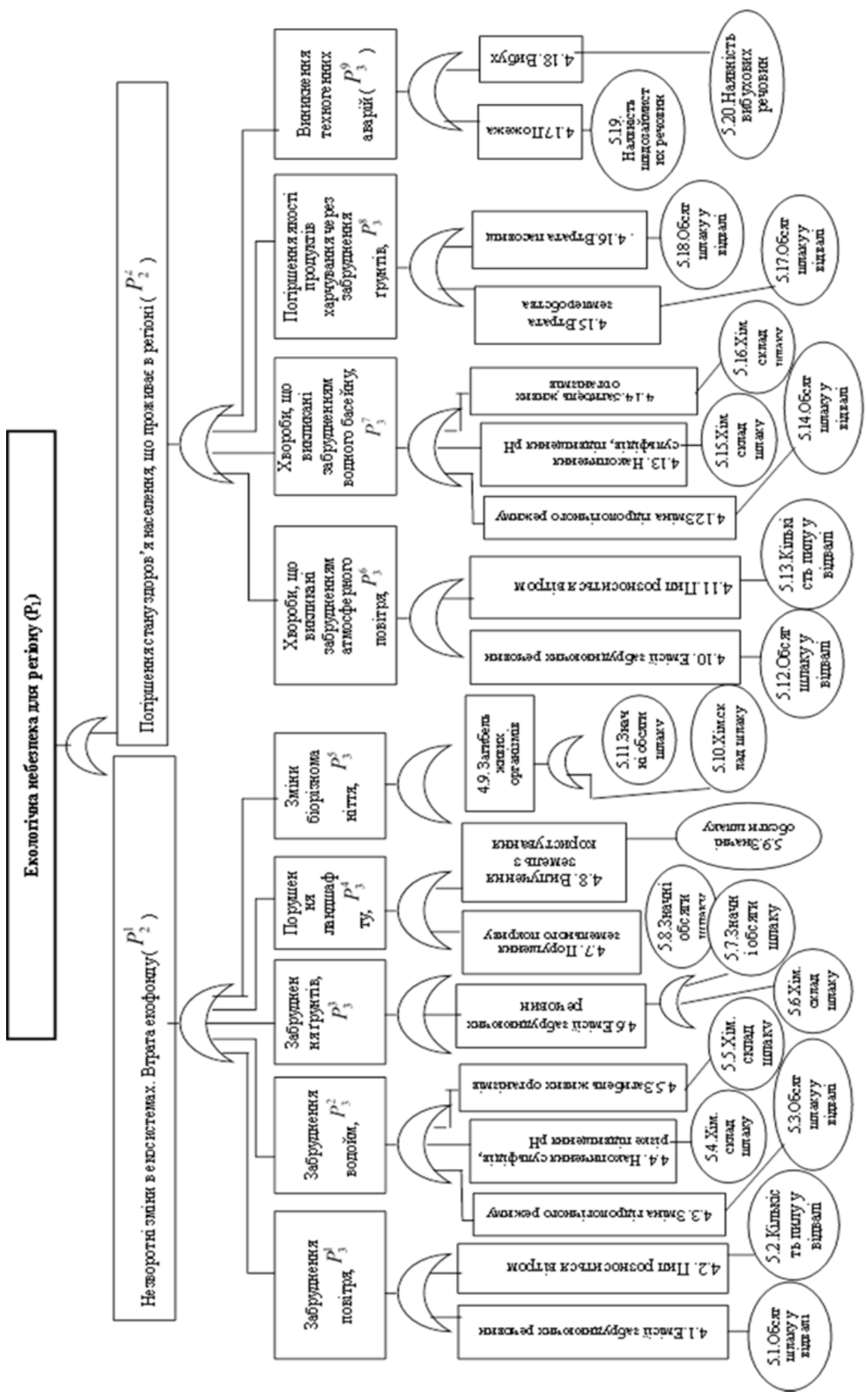

Рис. 2 - Логічний вираз “дерева відмов“ для визначення рівня екологічного ризику впливу відвалів металургійних шлаків м. Маріуполь 
Полігони для зберігання відходів металургійних комбінатів ПрАТ "Металургійний комбінат Азовсталь" та ПрАТ "Маріупольський металургійний комбінат імені Ілліча" розташовані поблизу зон проживання населення м. Маріуполя (0,5 км від житлового масиву "Найденівка", 1,65 км від ж/м "Слободка"). Відстань до Азовського моря від місць видалення відходів 0,04-0,6 км. До гирла р. Кальміус - 1,0-1,5 км. До р. Кальчик - 0,17 км. Річки та озера, які знаходяться поблизу шлакосховищ, забруднені і перетворені в сховища із забрудненою водою, в якій концентрація сульфідів досягає 1 г/л.

Все це створює значні ризики та небезпеки для здоров'я людей та навколишнього середовища. Для кількісної оцінки ризику було складено логічний вираз у вигляді "дерева відмов", що пов'язує ймовірність головної події з ймовірностями основних подій (рис. 2).

Позначимо головну подію, яка характеризує рівень екологічного ризику та небезпеки від впливу відвалів металургійних комбінатів для регіону, як $\mathrm{P}_{1}$. Подіями другого рівня $\epsilon$ незворотні зміни в екосистемах і втрата екофонду $\left(P_{2}^{1}\right)$ та погіршення стану здоров'я населення, що проживає в регіоні $\left(P_{2}^{2}\right)$. Небезпека наявна від кожної з цих подій. Отже, в логічній схемі використовується оператор "АБО". Ймовірність виникнення подій третього рівня позначаємо як $P_{3}^{1}-P_{3}^{9}$. Кожна 3 них може викликати одну 3 подій другого рівня. Позначимо події четвертого рівня як $P_{4}^{1}-P_{4}^{18}(4.1-4.18)$. П'ятого - $P_{5}^{1}-P_{5}^{20}(5.1-5.20)$. Номери подій представлені в "дереві відмов" - рис. 2.

Логіка всіх подій передбачає використання в логічній схемі оператора "АБО". Для розрахунку ймовірності виникнення головної події - небезпечної ситуації з високим рівнем екологічної небезпеки у відвалах металургійних комбінатів використовували формули (1-2).

На основі зібраних даних про імовірність реалізації елементарних подій у "дереві відмов" для логіко-ймовірнісної моделі відмов, отриманої в процесі аналізу (рис. 2), було розраховано ймовірність виникнення екологічно небезпечної ситуації або аварії, пов'язаної з місцями зберігання шлаків металургійних ПрАТ "Металургійний комбінат Азовсталь" та ПрАТ "Маріупольський металургійний комбінат імені Ілліча“.

Для початкових подій п'ятого рівня необхідно визначити імовірність їх реалізації. Для цих цілей використовуємо інформацію, що міститься в технічній документації та базах даних металургійних комбінатів, у довідковій чи нормативній літературі та статистичних даних щодо охорони праці Маріупольської міської ради та Департаменту екології та природних ресурсів Донецької обласної державної адміністрації. Ймовірність реалізації початкових подій п'ятого рівня представлена множиною:

$$
P_{5}^{i}=(0,06 ; 0,089 ; 0,025 ; 0,035 ; 0,105 ; 0,084 ; 0,042 ; 0,051 ; 0,042 ; 0,072 ; 0,098 ;
$$

$0,074 ; 0,008 ; 0,006 ; 0,035 ; 0,036 ; 0,027 ; 0,045 ; 0,036 ; 0,03)$,

$i=1,20$.

Визначення ймовірності виникнення подій четвертого рівня:

$$
\begin{aligned}
P_{4}^{1}=P_{5}^{1}=0,06 ; P_{4}^{2}=P_{5}^{2}=0,089 ; \quad P_{4}^{3}=P_{5}^{3}=0,025 ; & P_{4}^{6}=1-\left(1-P_{5}^{6}\right)\left(1-P_{5}^{7}\right)=0,122 ; \\
P_{4}^{4}=P_{5}^{4}=0,035 ; P_{4}^{5}=P_{5}^{5}=0,105 ; & P_{5}^{8}=0,051 ;
\end{aligned}
$$


$P_{4}^{8}=P_{5}^{9}=0,042 ; P_{4}^{9}=1-\left(1-P_{5}^{10}\right)\left(1-P_{5}^{11}\right)=0,163 ; P_{4}^{10}=P_{5}^{12}=0,074 ;$

$P_{4}^{11}=P_{5}^{13}=0,008 ; P_{4}^{12}=P_{5}^{14}=0,006 ;$

$P_{4}^{13}=P_{5}^{15}=0,035 ; 0 P_{4}^{14}=P_{5}^{16}=0,036 ; P_{4}^{14}=P_{5}^{16}=0,027 ; P_{4}^{14}=P_{5}^{16}=0,045 ;$

$P_{4}^{15}=P_{5}^{17}=0,036 ; P_{4}^{15}=P_{5}^{17}=0,03$.

Розрахунок ймовірності виникнення подій третього рівня:

$P_{3}^{1}=1-\left(1-P_{4}^{1}\right)\left(1-P_{4}^{2}\right)=0,144 ; \quad P_{3}^{2}=1-\left(1-P_{4}^{3}\right)\left(1-P_{4}^{4}\right)\left(1-P_{4}^{5}\right)=0,138 ;$

$P_{3}^{3}=P_{3}^{6}=0,122 ; P_{3}^{4}=1-\left(1-P_{4}^{7}\right)\left(1-P_{4}^{8}\right)=0,91$;

$P_{3}^{5}=P_{3}^{9}=0,163 ; P_{3}^{6}=1-\left(1-P_{4}^{10}\right)\left(1-P_{4}^{11}\right)=0,81$;

$P_{3}^{7}=1-\left(1-P_{4}^{12}\right)\left(1-P_{4}^{13}\right)\left(1-P_{4}^{14}\right)=0,075 ; \quad P_{3}^{8}=1-\left(1-P_{4}^{15}\right)\left(1-P_{4}^{16}\right)=0,071 ;$

$P_{3}^{9}=1-\left(1-P_{4}^{17}\right)\left(1-P_{4}^{18}\right)=0,065$.

Розрахунок ймовірності виникнення подій другого рівня:

$$
P_{2}^{1}=1-\left(1-P_{3}^{1}\right)\left(1-P_{3}^{2}\right)\left(1-P_{3}^{3}\right)\left(1-P_{3}^{4}\right)\left(1-P_{3}^{5}\right)=0,507 \text {; }
$$

$P_{2}^{2}=1-\left(1-P_{3}^{6}\right)\left(1-P_{3}^{7}\right)\left(1-P_{3}^{8}\right)\left(1-P_{3}^{9}\right)=0,262$.

Ймовірність виникнення головної події становить $P_{1}^{1}=1-\left(1-P_{2}^{1}\right)\left(1-P_{2}^{2}\right)=0,636$.

Узагальнення результатів досліджень [22, 23] показали, що для всіх металургійних комбінатів шлакові матеріали зможуть забезпечити необхідну якість дорожнього матеріалу та необхідний модуль пружності 350-450 МПа. Це дозволяє використовувати цей матеріал в КДО. Заміна природного матеріалу на відходи металургійних комбінатів не знижує міцнісні характеристики дорожнього полотна.

Для впровадження одержаних результатів та проектування конструкції дорожнього одягу 3 альтернативним дорожньо-будівельним матеріалом обрано ділянку дороги I категорії на 173,1-199,4 км траси Київ-Одеса довжиною 26 км 34 смугами руху (рис. 3). Дорога проходить у V-III дорожньокліматичній зоні. Термін експлуатації дорожнього одягу 11 років.

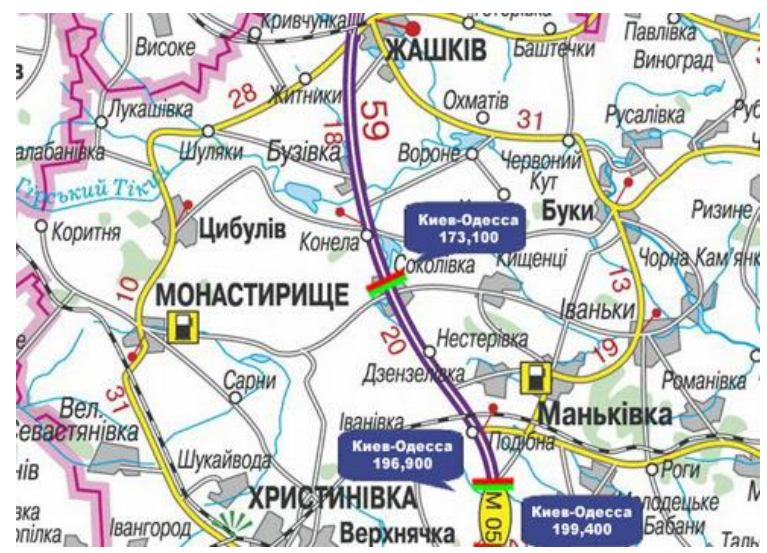

Рис. 3 - Схема АД "Київ-Одеса" 
Запропонована КДО з використанням в основі в основі шлакового щебеню має такий склад (табл. 3).

Таблиця 3 - КДО з використанням в основі шлакового щебеню

\begin{tabular}{|c|l|c|}
\hline $\begin{array}{c}\text { № } \\
\text { п/п }\end{array}$ & \multicolumn{1}{|c|}{ Матеріал, що використовується для КДО } & $\begin{array}{c}\text { Розмір } \\
\text { шару, см }\end{array}$ \\
\hline 1 & Асфальтобетон щільний на бітумі БНД - 40/60 & 9 \\
\hline 2 & Асфальтобетон пористий на бітумі БНД -60/90 & 6 \\
\hline 3 & Асфальтобетон пористий на бітумі БНД - 90/130 & 7 \\
\hline 4 & $\begin{array}{l}\text { Гравійно-піщана суміш неоптимального складу, } \\
\text { укріплена цементом І класу міцності }\end{array}$ & 14 \\
\hline 5 & Щебінь шлаковий & 20 \\
\hline 6 & Щебінь рядовий гранітний фракції 0-70 & 10 \\
\hline
\end{tabular}

Результати розрахунку конструкцій дорожнього одягу показали, що запропонована конструкція відповідає вимогам ВБН В.2.3-218-186-2004 [18], тобто є міцною i може бути застосована при будівництві. Розрахунки показують, що вміст металургійного шлаку в запропонованих КДО досягає $25 \ldots 32 \%$. Для доріг I категорії можна використати 30\%-32\% металургійних шлаків в КДО, для доріг II категорії - 27\%-29\% та для доріг III категорії $25 \%-26 \%$ (рис. 4). При цьому, під час будівництва 1 км дороги 3 використанням металургійних шлаків як замінника природних матеріалів у КДО може звільнятись $15,5 \cdot 10^{3} \mathrm{~m}^{3}$ обсягу шлакового відвалу. Для всієї досліджуваної дороги цей обсяг складає $2,68 \cdot 10^{6}-3,09 \cdot 10^{6} \mathrm{~m}^{3}$. В цьому випадку рівень екологічного ризику буде визначатись ймовірністю виникнення головної події і дорівнювати 0,4452-0,4643. Рівень екологічної безпеки регіону за рахунок зменшення обсягу металургійних шлаків може бути підвищений на 27-30\%, що дозволить підприємству одержати сумарний еколого-економічний ефект у сумі 1,22 млн грн.

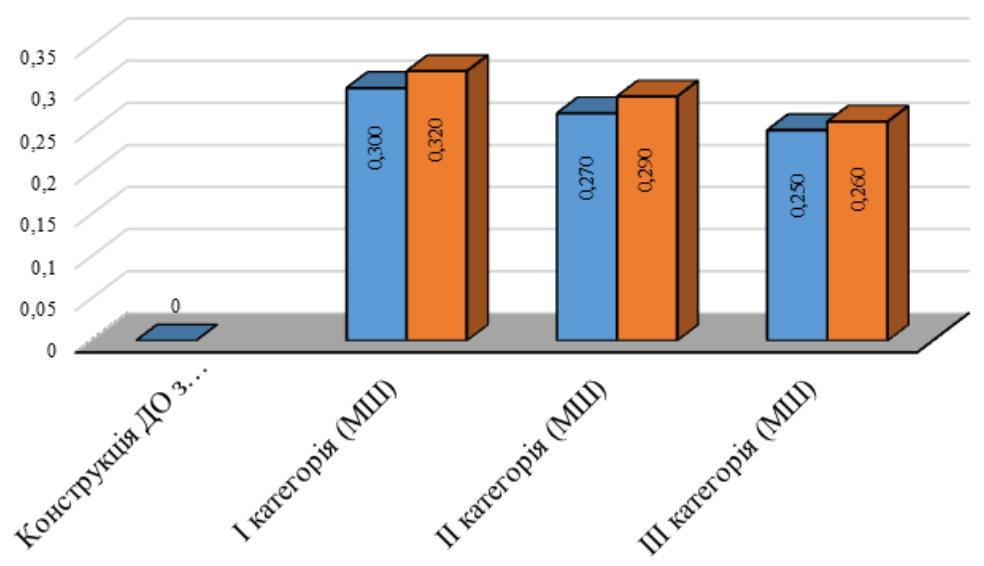

口Min товщина шару, м 口Мах товщина шару, м

Рис. 4 - Порівняльний аналіз екологічного критерію при заміні природних матеріалів металургійними шлаками для різних категорій доріг 


\section{Висновки}

Таким чином, на основі зібраних даних про імовірність реалізації елементарних подій у "дереві відмов" для логіко-ймовірнісної моделі відмов, отриманої в процесі аналізу, розраховано ймовірність виникнення екологічно небезпечної ситуації або аварії, пов'язаної з місцями зберігання шлаків металургійних ПрАТ "Металургійний комбінат Азовсталь" та ПрАТ "Маріупольський металургійний комбінат імені Ілліча". Ризик небезпеки збереження шлаків у відвалах металургійних комбінатів виникнення головної події становить 0,636. Основними факторами, що створюють екологічну небезпеку, є наявний обсяг шлаків та шлакового пилу на території відвалу. Розроблено конструкції дорожнього одягу з використанням металургійних шлаків. Вміст металургійного шлаку в запропонованих КДО досягає 25...32\%. Використання металургійних шлаків, які є малотоксичними відходами, тобто відходами IV класу небезпеки, у дорожньому будівництві дозволить знизити рівень наявного екологічного ризику за умови надання металургійним шлакам споживчих властивостей. Рівень екологічної безпеки регіону за рахунок зменшення обсягу металургійних шлаків може бути підвищений на 27-30\%, що дозволить підприємству одержати сумарний еколого-економічний ефект у сумі 1,22 млн грн.

\section{Назва і номер проекту}

Дослідження були виконані в рамках науково-дослідних тематик: "Розробка технологій поводження з відходами в транспортно-дорожньому комплексі", реєстраційний номер 0107U009610, 2010 р. та "Удосконалення та розробка методів екологічної безпеки та безпеки життєдіяльності" реєстраційний номер 0118U001109, 2017-2018 pp.

\section{СПИСОК ЛІТЕРАТУРИ}

1. World Steel Association. Режим доступу: https://www.worldsteel.org/

2. World Steel in Figures 2018 now available. Режим доступу: https://www.worldsteel.org/ media-centre/press-releases/ 2018/world-steel-in-figures-2018.html

3. Укрметалургпром. Аналітичні дані. Режим доступу: http://www.ukrmetprom.org/ analitichni-dani/

4. Фещенко О. Л. Оцінка впливу діяльності металургійних підприємств на навколишнє природне середовище України / О. Л. Фещенко, Н. В. Каменева // Інвестиції: практика та досвід. - 2016. - № 2. - С. 28-32. - Режим доступу: http://nbuv.gov.ua/UJRN/ipd_20162_8. 5. Большина Е.П. Экология металлургического производства: учебн. пособ. / Е.П. Большина. - Новотроицк: НФ НИТУ "МИСиС", 2012. - 155 с.

6. Рудь В. Аналіз кількості утворених відходів машинобудування та металургії на території України / В. Рудь, І. Савюк, Л. Самчук, Ю. Повстяна // Вісник Тернопільського національного технічного університету. - 2015. - № 3. - С. 130-136. Режим доступу: http://nbuv.gov.ua/UJRN/tstub_2015_3_20.

7. Н.Н. Рулев, В.Я. Королев, В.В. Лукьянова, О.В. Кравченко / Ультрафлокуляция как метод повышения эффективности процесса извлечения тонкодисперсного угля из хвостов обогащения // Збагачення корисних копалин: Наук.-техн. зб. - 2010. Вип. 40(81). - С. 119-125. - Режим доступу: http://ir.nmu.org.ua/handle/123456789/152981 8. Крюковська Л.І., Хрутьба В.О. Математичне моделювання властивостей металургійних шлаків як дорожньо-будівельного матеріалу / Л.І. Крюковська, 
В.О. Хрутьба // Науково-технічний збірник "Автомобільні дороги i дорожнє будівництво" - 2017. - Вип. 100. - С. 97-104. - Режим доступу: http://publications.ntu. edu.ua/avtodorogi_i_stroitelstvo/100/097-104.pdf

9. Лесовик В.С. Гранулированные шлаки в производстве композиционных вяжущих / В.С. Лесовик, М.С. Агеева, А.В. Иванов. // Вестник БГТУ им. В.Г. Шухова. - 2011. № 3. - C. 29-32.

10. Данилова Т.Г. Підвищення екологічної безпеки при поводженні з відходами металургійного виробництва. - Дис...канд.техн.наук: 21.06.01 - "Екологічна безпека". Приазовський технічний ун-т, Маріуполь, 2004 - 200 с.

11. Котов Ю.Т. Аналіз утворення відходів металургійного виробництва і розробка методів їх повторного використання на ПАТ "АрселорМіттал Кривий Ріг" / Ю.Т. Котов, Ф.С. Разкевич, К.В. Гончарова // Гірничий вісник. - 2012. - Вип. 95. С. 232-236. - Режим доступу: http://nbuv.gov.ua/UJRN/girvi_2012_95 63

12. Сгоров К.В. Аналіз відходів металургійного виробництва. Спеціальна металургія: вчора, сьогодні, завтра. 2010, С. 193-196. Режим доступу: http://www.fhotm.kpi.ua/sworks/05/egorov_article_2010.pdf

13. Каут О.В. Галузь чорної металургії як середовище виникнення ризиків / О.В. Каут // Стратегічні пріоритети. - 2015. - № 2. - С. 79-86. - Режим доступу: http://nbuv.gov.ua/UJRN/spa_2015_2_12.

14. Хрутьба В.О. Вайганг Г.О., Крюковська Л.І. Визначення показників екологічної безпеки проектів використання відходів як дорожньо-будівельного матеріалу Науковий журнал “Технічний аудит та резерви виробництва", № 4, 2015, С. 64-71. DOI: $10.15587 / 2312-8372.2015 .47724$

15. Мальований М.С., Шмандій В.М., Харламова О.В. і ін. Аналіз та систематизація існуючих методів оцінювання ступеня екологічної небезпеки // Екологічна безпека. 2013. - No 1(15). - C. 37-44 - Режим доступу: http://www.kdu.edu.ua/EKB_ jurnal/2013_1(15)/Pdf/37.pdf

16. Методика визначення ризиків і їх прийнятих рівнів для декларування безпеки об'єктів підвищеної небезпеки - Режим доступу: https://zakon.rada.gov.ua/rada/show/v0637203-02

17. ВБН В.2.3-218-186-2004 Споруди транспорту. Дорожній одяг нежорсткого типу. Режим доступу: https://dnaop.com/html/40602/doc\%D0\%92\%D0\%91\%D0\%9D_\%D0\% 92.2.3-218-186-2004

18. ГБН В.2.3-218-007:2012 Екологічні вимоги до автомобільних доріг. Проектування. Київ. Державне Агентство автомобільних доріг України. (Укравтодор). 2012. - 46 с. Режим доступу: http://kbu.org.ua/assets/app/documents/dbn2/122.1..pdf

19. Делеган-Кокайко С.В., Слабкий Г.О., Лук'янова В.В., Анпілова Є.С. Вплив сміттєзвалищ на показники захворюваності сільського населення та поширеності серед нього хвороб. - Ecological safety and natural resources. - К., 2020. - №2 (34) C. 43-52. DOI: https://doi.org/10.32347/2411-4049.2020.2.43-52

20. Department of Ecology and Natural Resources of Donetsk Regional State Adinistration http://ecology.donoda.gov.ua/

21. Екологічний паспорт Донецької області Донецька обласна державна військовоцивільна адміністрація. 2017 p. - 196 c. http://ecology.donoda.gov.ua/stan-dovkillya/ ekologichnij-pasport/

22. Крюковська Л.І. До оцінювання властивостей дорожнього одягу з використанням в конструкції альтернативних матеріалів / Л.І. Крюковська // Вісник Національного транспортного університету. - 2010. - № 20. - С. 233-237. - Режим доступу: http://nbuv.gov.ua/UJRN/Vntu_2010_20_42.

23. Хрутьба В.О. Систематизація конструкцій дорожнього одягу нежорсткого типу 3 використанням альтернативних матеріалів / В.О. Хрутьба, Л.І. Крюковська // Вісник Національного транспортного університету. - 2012. - № 25. - С. 400-404.

Стаття надійшла до редакиії 05.03.2021 і прийнята до друку після рецензування 24.05.2021 


\section{REFERENCES}

1. World Steel Association. Retrieved from: https://www.worldsteel.org/

2. World Steel in Figures 2018 now available. Retrieved from: https://www.worldsteel.org/media centre/press-releases/ 2018/world-steel-in-figures2018.html

3. Ukrmetalurgprom. Analytical data. Retrieved from: http://www.ukrmetprom.org/analitichni-dani/ (in Ukrainian).

4. Feshhenko, O., \& Kameneva, N. (2016). Assessment of the imact of the activities of metallurgical enterprises on the environmental in Ukraine. Investytsiyi: praktyka ta dosvid, 2, 28-32. http://nbuv.gov.ua/UJRN/ipd_2016_2_8 (in Ukrainian).

5. Bolshina, E.P. (2012). Ecology of metallurgical production: a manual. Novotroitsk: NF NITU "MISiS" (in Russian).

6. Rud', V., Saviuk, I., Samchuk, L., \& Povstyana, Y. (2015). Analysis of the amount of generated waste of mechanical engineering and metallurgy on the territory of Ukraine. Visnyk Ternopil's'koho natsional'noho tekhnichnoho universytetu, 79, 3, 130-136. http://nbuv.gov.ua/UJRN/tstub_2015_3_20 (in Ukrainian).

7. Rulyov, N.N., Korolyov, B.Y., Lukianova, V.V., \& Kravtchenko, O.V. (2010). Ultraflocculation - as a method of increasing the efficiency of the process of extracting finely dispersed coal from the tailings. Zbagachennya korisnykh kopalin: Nauk.-tekhn. zb., 40 (81), 119-125. http://ir.nmu.org.ua/handle/123456789/152981 (in Russian).

8. Khrutba, V.A., \& Kriukovska, L.I. (2017). Mathematical modeling of properties of metallurgical slags as road-building material. Scientific and technical journal "Automobile roads and road construction", 100, 97-104. http://publications.ntu.edu.ua/avtodorogi_i_stroitelstvo/100/097-104.pdf (in Ukrainian).

9. Lesovik, V.S., Agaev, M.S., \& Ivanov, A.V. (2011). Granulated slags in the production of composite binders. Vestnik BSTU them. Im. Shukhov, 3, 29-32 (in Russian).

10. Danilova, T. G. (2004). Increase of ecological safety at handling of metallurgical waste. (dissertation). Priazovsky Technical University, Mariupol, Ukraine (in Ukrainian).

11. Kotov, Yu.T., Razkevich, F.S., \& Goncharova, K.V. (2012). Analysis of the formation of waste metallurgical production and development of methods for their re-use at PJSC "ArcelorMittal Krivoy Rog". Mining Bulletin, 95, 232-236. http://nbuv.gov.ua/UJRN/girvi_2012_95_63 (in Ukrainian).

12.Egorov K.V. (2010) Metallurgical Waste Analysis. Special Metallurgy: Yesterday, Today, Tomorrow, 193-196. http://www.fhotm.kpi.ua/sworks/05/egorov_article_2010.pdf 13. Kaut, O.V. (2015). Steel industry as a lane environment. Strategic priorities, 2 (35), 79-86. http://nbuv.gov.ua/UJRN/spa_2015_2_12 (in Ukrainian).

14. Khrutba, V., Weigang, G., \& Krukovskaja, L. (2015). Determining the indicators of environmental safety of projects using waste as a road construction material. Technology audit and production reserves, 4/4 (24), 64-71. DOI: 10.15587/2312-8372.2015.47724 (in Ukrainian).

15. Malovanyy, M., Shmandiy, V., Kharlamova, O., Chelyadin, L., \& Sakalova, G. (2013). Analysis and systematization of existent methods of degree of ecological danger. Ecological safety, $\quad 1$ (15), 37-44. http://www.kdu.edu.ua/EKB_jurnal/2013_1(15)/Pdf/37.pdf (in Ukrainian).

16. Methodology for determining the risks and their adopted levels for declaring the safety of high-risk objects. Retrieved from: https://zakon.rada.gov.ua/rada/show/v0637203-02 17. VBN B.2.3-218-186-2004 Constructions of transport. Non-rigid type of road clothes. Retrieved from: https://dnaop.com/html/40602/doc-\%D0\%92\%D0\%91\%D0\%9D_\%D0\% 92.2.3-218-186-2004

18. GBN B.2.3-218-007:2012. (2012). Ecological requirements for highways. Designing. Kiev. State Agency of Motor Roads of Ukraine. (Ukravtodor). http://kbu.org.ua/assets/app/documents/dbn2/122.1..pdf 
19. Delegan-Kokayko, S.V., Slabkiy, G.O., Lukianova, V.V., \& Anpilova, E.S. (2020). Influencing smittusvalisch on indicators of sickness of the Silskoe population and the wideness of the middle ailment. Ecological safety and natural resources, 2 (34), 43-52. DOI: https://doi.org/10.32347/2411-4049.2020.2.43-52 (in Ukrainian).

20. Department of Ecology and Natural Resources of Donetsk Regional State Administration Retrieved from: http://ecology.donoda.gov.ua/

21. Ecological passport of Donetsk region. (2017). Donetsk Regional State Military and Civil Administration. Retrieved from: http://ecology.donoda.gov.ua/stan-dovkillya/ekologichnijpasport/

22. Kriukovska, L.I. (2010). To evaluate the properties of road clothing with the use of alternative materials. Visnuk of the National Transport University, 20, 233-237. http://nbuv.gov.ua/UJRN/Vntu_2010_20_42. (in Ukrainian).

23. Khrutba, V.A., \& Kriukovska, L.I. (2012). Systematic design of non-rigid type of road cloths using alternative materials. Visnuk of the National Transport University, 25, 400-404 http://nbuv.gov.ua/UJRN/Vntu_2012_25_77 (in Ukrainian).

The article was received 05.03.2021 and was accepted after revision 24.05.2021

\section{Хрутьба Вікторія Олександрівна}

доктор технічних наук, професор, завідувач кафедри екології та безпеки життєдіяльності Національного транспортного університету

Адреса робоча: 01010 Київ, вул. Омеляновича-Павленка, 1

ORCID ID http://orcid.org/0000-0002-8121-2042,e-mail: Viktoriia.Khrutba@gmail.com

\section{Нікітченко Юлія Станіславівна}

кандидат технічних наук, доцент кафедри екологічного менеджменту та підприємництва Київського національного університету імені Тараса Шевченка Адреса робоча: 03054 Київ, вул. Васильківська, 90а

ORCID ID http://orcid.org/0000-0003-1487-641X,e-mail: julia_n_s@ukr.net

\section{Крюковська Леся Іванівна}

кандидат технічних наук, доцент кафедри екології та безпеки життєдіяльності Національного транспортного університету

Адреса робоча: 01010 Київ, вул. Омеляновича-Павленка, 1

ORCID ID https://orcid.org/0000-0001-8944-8036,e-mail: krjukovska@gmail.com

\section{Лук'янова Віталіна Віталіївна}

кандидат хімічних наук, доцент кафедри екології та безпеки життєдіяльності Національного транспортного університету

Адреса робоча: 01010 Київ, вул. Омеляновича-Павленка, 1

ORCID ID http://orcid.org/0000-0001-8964-3560,e-mail: vitalina_lk@i.ua

\section{Спасіченко Оксана Вікторівна}

асистент кафедри екології та безпеки життедіяльності Національного транспортного університету

Адреса робоча: 01010 Київ, вул. Омеляновича-Павленка, 1

ORCID ID https://orcid.org/0000-0002-7809-6765, e-mail: o.spasichenko@ntu.edu.ua 